\title{
Evaluation of ibuprofen and diclofenac in the main rivers of Colombia and striped catfish Pseudoplatystoma magdaleniatum.
}

\section{Sara E. Gallego Ríos ( $\square$ sara.gallego@udea.edu.co )}

Universidad de Antioquía https://orcid.org/0000-0002-5143-1869

Gustavo A. Peñuela

Universidad de Antioquia

\section{Original Research}

Keywords: Nonsteroidal anti-inflammatory drugs, Fish, Surface water, Contamination, QuEChERS, UHPLCMS/MS

Posted Date: January 29th, 2021

DOI: https://doi.org/10.21203/rs.3.rs-165887/v1

License: (c) (i) This work is licensed under a Creative Commons Attribution 4.0 International License.

Read Full License

Version of Record: A version of this preprint was published at Environmental Monitoring and Assessment on March 23rd, 2021. See the published version at https://doi.org/10.1007/s10661-021-08922-5. 


\section{Abstract}

This is one of the first studies carried out over three climatic seasons on the determination of ibuprofen and diclofenac, in the main rivers of Colombia and striped catfish Pseudoplatystoma magdaleniatum. Determination of water concentrations was carried out using SPE extraction, while for the analysis of the muscular tissue the extraction was carried out by QuEChERS. For both matrices, quantification was done by UHPLC-MS/MS. No levels of ibuprofen or diclofenac concentrations were found in muscle tissue of Pseudoplatystoma magdaleniatum, in any season or sampling site, during the two years of sampling. In some sampling sites, concentrations of up to $75 \mu \mathrm{g} / \mathrm{L}$ of diclofenac were detected, corresponding to the sampling carried out in the dry season, being the highest reported so far in surface waters, possibly generated by large concentrations of population or agricultural activities. On the other hand, for ibuprofen, no concentrations above the limit of quantification $(0.50 \mu \mathrm{g} / \mathrm{L})$ were found in the waters of the Cauca and Magdalena rivers, for any season and sampling site.

\section{Introduction}

Non-steroidal anti-inflammatory drugs (NSAIDs) are one of the most important groups of pharmaceutical products since they are the most highly-used in primary health care and therefore the most highlyconsumed worldwide. (Saravanan et al. 2012; Zhang et al. 2020). Ibuprofen (2-(4-Isobutylphenyl) propanoic acid) and diclofenac (2-[2-(2,6-dichloroanilino) phenyl] acetic acid) are the most highly-used NSAIDs worldwide; their global consumption can exceed 10,000 tons of ibuprofen/year and 14,000 tons of diclofenac/year (Memmert et al. 2013; Zhang et al. 2020). Ibuprofen is a widely used medicine, classified as an essential medicine by the WHO in 2019 (WHO Technical Report Series 2019). In Colombia, ibuprofen occupies second place in health records granted, $57 \%$ of sales being with a prescription and the rest over-the-counter(Vianneth and Roa 2013); while diclofenac has the highest number of health records granted, $89 \%$ of sales being with a prescription and the rest over-the-counter (Vianneth and Roa 2013).

Due to the availability of these drugs in water bodies, they have been easily detected in rivers and streams from $\mathrm{ng} / \mathrm{L}$ to $\mu \mathrm{g} / \mathrm{L}$ (Nallani et al. 2011; Wabaidur et al. 2015) and in wastewater treatment plant effluents in the order of $\mu \mathrm{g} / \mathrm{L}$ (Afonso-Olivares et al. 2017), since their elimination is incomplete during wastewater treatment processes (Saravanan et al. 2012; Zhang et al. 2020). Ibuprofen has been detected in rivers $(1.681-33.764 \mu \mathrm{g} / \mathrm{L})$ (Petrie et al. 2014), in influents $(<0.984-6.328 \mu \mathrm{g} / \mathrm{L})$ and effluents $(<0.065-0.491$ $\mu \mathrm{g} / \mathrm{L}$ ) from wastewater treatment plants (Kasprzyk-Hordern et al. 2009), as well as in fish tissues (<LOQ$93.5 \mathrm{ng} / \mathrm{g}$ ) (Ali et al. 2018) and bile (nd-34 ng/mL) (Brozinski et al. 2013). This medicine can cause alterations in reproduction and development (Vianneth and Roa 2013), oxidative stress, hematological changes $(0.1,1.0$, and $10 \mu \mathrm{g} / \mathrm{L}$ ) (Mathias et al. 2018), and DNA damage in fish (66.4 ng/L) (Rocco et al. 2010). Diclofenac, in 2015 was included in the European Union (EU) Emerging Pollutant Watch List in the European Water Framework Directive (European Commission 2015), however, it was removed from the Watch List in 2018 (European Commission 2018). The maximum concentrations of diclofenac found were $7.1 \mu \mathrm{g} / \mathrm{L}$ in the effluents of the WWTP, $4.7 \mu \mathrm{g} / \mathrm{L}$ in the effluents and $203 \mu \mathrm{g} / \mathrm{L}$ in the wastewater of 
the pharmaceutical manufacturers, and in fish muscle from $0.2 \mathrm{ng} / \mathrm{g}$ (Liu et al. 2015) to $1812 \mathrm{ng} / \mathrm{g}$ (Ojemaye and Petrik 2019).

Ibuprofen and diclofenac interfere with the cyclooxygenase pathway, decreasing the catalysis of prostaglandin biosynthesis from arachidonic acid. Prostaglandins are responsible for important physiological functions, acting as "local" hormones in reproduction, water transport, and osmoregulation processes (Chen et al. 2014; Gonzalez-Rey and Bebianno 2012; Han et al. 2010; Schmidt et al. 2011). These drugs are designed to be biologically active, and once they enter the water can affect fish (Brozinski et al. 2013; Stancova et al. 2017). These effects include modifications to cellular reactions in the liver, kidney, and gills (Paíga et al. 2015; Schmidt et al. 2011); and disruption of the endocrine system through alteration to the activity of aromatase, influencing the balance of sex hormones; and cytological and histological effects and changes in gene expression (Guiloski et al. 2015).

Specifically, ibuprofen, at concentrations of $4.17 \mu \mathrm{g} / \mathrm{L}, 1.39 \mu \mathrm{g} / \mathrm{L}$, and $3.0 \mu \mathrm{g} / \mathrm{L}$ in Cyprinus carpio produce disorders of embryonic development and teratogenic effects, such as delayed hatching, hypopigmentation, pericardial edema, deformation of the bud, and development (Gutiérrez-Noya et al. 2020). In Rhamdia chelen at concentrations of $10 \mu \mathrm{g} / \mathrm{L}$, in the posterior kidney, the activity of glutathioneS-transferase, glutathione peroxidase, increases; in blood, the white blood cell count decreased in the groups exposed to 0.1 and $1.0 \mu \mathrm{g} / \mathrm{L}$, which indicates that ibuprofen causes nephrotoxicity and demonstrated an immunosuppressive effect (Mathias et al. 2018). On the other hand, exposures of diclofenac between 1 - $500 \mu \mathrm{g} / \mathrm{L}$ for 28 days in Oncorhynchus mykiss, showed degeneration of hyaline droplets of tubular epithelial cells in the kidney and the appearance of interstitial nephritis; in gills, necrosis of the pillar cells, which produced damage to the capillary wall within the secondary lamellae. The lowest concentration with effects observed in both the kidney and the gills was $5 \mu \mathrm{g} / \mathrm{L}$; Also, there was an accumulation of diclofenac in the different organs analyzed, mainly in the liver, followed by the kidney, gills, and muscle tissue (Schwaiger et al. 2004). Another study in Argyrosomus regiusa with exposure to this same drug at 0.3 and $15 \mu \mathrm{g} / \mathrm{L}$ for 30 days, affecting the metabolism of fish by increasing the consumption of cellular energy in the muscle and, consequently, reducing the net energy budget of the fish (Duarte et al. 2020).

In the last 40 years, an $80 \%$ decrease in the number of striped catfish Pseudoplatystoma magdaleniatum has been detected in the Magdalena and Cauca river basins of Colombia (De La Hoz-M et al. 2014a, 2014b; González et al. 2014). This decrease threatens the economy of the communities where catfish live, where they are the main source of work, income, and food (Garcia et al. 2003). P. magdaleniatum (Siluriformes, Pimelodidae) is endemic, and is the most commercially important species in the Colombian fishery; however, it is a critically endangered species (Mojica et al. 2012). The causes of this decrease include the degradation of its habitats, river impoundment, overfishing, deforestation, and organic and inorganic pollution (Herrera-Cruz et al. 2019; Mojica et al. 2012, 2016). This fish inhabits Colombia's main rivers, which cross much of the country, collecting a large quantity and variety of domestic, industrial, and agricultural pollutants (Kraak 2002; Romano Mozo 2012). Colombia's processes for monitoring pharmaceutical waste in rivers and effluents from wastewater treatment plants are in the incipient stage, 
which leads to a lack of knowledge regarding the destination, transport, and toxicity levels of these products in both water resources and fish, resulting in serious and potentially irreversible effects (García Gómez et al. 2011; Meador et al. 2016; Mottaleb et al. 2015; Naidu et al. 2016; Pal et al. 2014; Peña Álvarez and Castillo Alanís 2015; Vandermeersch et al. 2015).

Considering the above, a study was carried out to determine the current status of the presence of ibuprofen and diclofenac in the main rivers of Colombia, the Cauca, and the Magdalena. Five sites were monitored in each of the rivers, following the modified EPA Method 1694 (Environmental Protection Agency (EPA) et al. 2007), in the different climatic seasons (rain, transition, dry). Also, the concentration of these two pharmaceutical products in muscle tissue of striped catfish $P$. magdaleniatum in each of the sampling sites was determined, following the QuEChERS methodology. For the quantification, an ultraperformance liquid chromatography-tandem mass spectrometer (UHPLC-MS/MS) was used. Eight water and fish samplings were carried out during the years 2018-2019.

\section{Materials And Methods}

\subsection{Reagents, solvents, and materials}

The ibuprofen and diclofenac standards were purchased in USP (Rockville, MD, United States). Diclofenac-d 4 and Ibuprofen ${ }^{13} \mathrm{C}_{6}$ isotopically labeled standards were purchased from Toronto Research Chemicals (Ontario, Canada), Table 1.

LC-MS grade acetonitrile, LC-MS grade methanol, and $37 \%$ hydrochloric acid were supplied by Merck Millipore (Darmstadt, Germany). LC-MS glacial acetic acid was obtained from PanReac AppliChem (Castellar del Vallés, Barcelona). Ultrapure water (Type I) (18.2 $\mathrm{M} \Omega \mathrm{cm}$ resistivity) was produced using a Simplicity UV system (Millipore, Molsheim, France). Nitrogen of $99.999 \%$ purity was obtained from Linde, (Bogotá, Colombia).

Standard solutions (at a concentration of $1000 \mathrm{mg} / \mathrm{L}$ ) and isotopically marked standards were prepared on a weight basis in LC-MS methanol $(\mathrm{MeOH})$. All solutions were stored at $-20^{\circ} \mathrm{C}$, with an expiration time of three months. The mixture of standard working solutions containing all the compounds was prepared in MeOH LC-MS. A mixture with the isotopically labeled standards was prepared to be used for internal standard calibration.

Before the SPE all samples were filtered through glass wool (Santa Clara, CA, United States). The cartridges used for solid-phase extraction were OASIS HLB (60 mg, $3 \mathrm{ccs}$ ) from Waters (Milford, Massachusetts, USA). A Visiprep ${ }^{\text {TM }}$ SPE Vacuum Manifold system from SUPLECO (Darmstadt, Germany) was used for the SPE. Visidry ${ }^{\text {TM }}$ Drying Attachment system from SUPELCO (Darmstadt, Germany) was used to dry the samples with nitrogen

The homogenization of the muscle was used Hobart Combi Cutter CC34 industrial processor (Offenburg, Germany) and Ultra Turrax T25 (IKA, Germany); for the extraction Original QuEChERS were obtained from 
Agilent (Santa Clara, CA, United States) and Centrifuge 0320R (Boeco, Germany).

\subsection{UHPLC-MS/MS analysis}

The chromatographic analysis of ibuprofen and diclofenac in the muscle tissue and water samples was performed using Ultra-High-Performance Liquid Chromatography coupled with triple Quadrupole Mass Spectrometry Acquity H-Class from Waters (Milford, Massachusets, USA). The operation of the equipment and the quantification of the data was performed with MassLynx 4.1 software. Simultaneous determination of the two drugs was performed with a UHPLC KINETEX Core-Shell C18 column $(1.7 \mu \mathrm{m}$ C18 100A, $50 \times 2.1 \mathrm{~mm}$ ) from Phenomenex (Torrance, California, United States). To perform the separation, reversed-phase gradient elution was used as shown in Table 2, with a total execution time of $7.0 \mathrm{~min}$. The mobile phase consisted of $0.05 \%$ acetic acid $(A)$ and acetonitrile: $\mathrm{MeOH}(50: 50 \mathrm{v} / \mathrm{v})(B)$, with an injection flow of $0.3 \mathrm{~mL} / \mathrm{min}$ and injection volume of $20 \mu \mathrm{L}$.

The column was maintained at a temperature of $40^{\circ} \mathrm{C}$ and the sample at $15^{\circ} \mathrm{C}$. The capillary voltage of Waters Xevo TQD was set at $3.5 \mathrm{kV}$ for $\mathrm{ESI}^{-}$. The source temperature was set at $130^{\circ} \mathrm{C}$ and the desolvation gas temperature at $350^{\circ} \mathrm{C}$, with a flow of $1000 \mathrm{~L} / \mathrm{h}$ and a cone gas flow of $100 \mathrm{~L} / \mathrm{h}$. To obtain greater sensitivity of the two drugs, conditions such as precursor ion, retention times, cone voltage, collision energy, and ion ratios were optimized, and are described in detail in Table 3.

\subsection{Method validation, quality control, and calibration}

A validation study was carried out to demonstrate the applicability of the two analytical methods, water, and fish. The purpose of analytical measurements is to obtain reliable, accurate, and consistent data and for this, the verification of an analytical method for water analysis was performed, based on EPA 1694 Pharmaceuticals and Personal Care Products in Water, Soil, Sediment, and Biosolids by HPLC/MS/MS (Environmental Protection Agency (EPA) et al. 2007), with some modifications through solid-phase extraction (SPE) and quantification ultra-high-performance liquid chromatography coupled with triple quadrupole mass spectrometry (UHPLC-QqQ-MS/MS), with the source of electrospray ionization (ESI). It was performed following the requirements of Eurachem (Eurachem / CITAC 2015; EURACHEM / CITAC 2012), Directive 96/23/EC (Official Journal of the European Communities 2002), and the AOAC Official Methods of Analysis (AOAC Official Methods of Analysis 2016). In Table 4 for water and Table 5 for fish, the verification parameters considered for this study are described: confirmation of identity, selectivity, linearity, the limit of detection (LoD), the limit of quantification (LoQ), matrix effect, trueness, and precision, and uncertainty.

For fish samples, extraction was performed by QUEChERS, and quantification was performed by UHPLCQqQ-MS/MS. The performance of the developed method was presented in terms of confirmation of identity, selectivity, linearity, the limit of detection (LOD), the limit of quantification (LOQ), matrix effect, trueness, and precision, according to the same requirements of water analysis, applied to fish muscle tissue samples. The parameters for confirming identity and selectivity are equivalent to the water tests. 
Confirmation of identity was performed by mass spectrometry to confirm its identity based on its $\mathrm{m} / \mathrm{z}$ ratio. From the obtained spectra, it could be seen that the main component has $\mathrm{m} / \mathrm{z}$ at 205.12 and 294.10, which corresponds to ibuprofen and diclofenac. Transitions 1 for quantification (Q) and 2 for confirmation (q1 and q2) were automatically obtained in the infusion of the analyzed PPCPs (Table 3). The selectivity was carried out by optimizing the conditions, such as the appropriate ratio of the organic and aqueous phase, the ionization mode of the run time (ES -/+), the cone voltage, the capillary voltage, the temperature of desolvation, source temperature and desolvation gas flow, to achieve the best possible separation of drugs. The times in which ibuprofen and diclofenac elute with a good peak were at 4.02 and 3.99 minutes, respectively. Good resolution $(R>5.057)$ and high selectivity $(a>1)$ (Budiman and Zuas 2017) were obtained.

Seven-point calibration curves were prepared through a dilution of the standard solution mixture, using linear regression analysis with concentrations in the range of $0.5-10 \mu \mathrm{g} / \mathrm{L}$, for water and $20-400 \mathrm{ng} / \mathrm{g}$ for fish. The quantification of the analytes was performed using the external standard approach and internal standard verification. Type I water was used as a blank for the matrices in water, and for fish, the curve was made in the matrix.

The LOD and LOQ for the compounds were calculated as a signal-to-noise $(\mathrm{S} / \mathrm{N})$ ratio of 3: 1 and 10: 1, respectively (Environmental Protection Agency (EPA) et al. 2007; Paíga et al. 2015; Petrović et al. 2014). They were calculated using ten different samples of a blank and ten samples of a blank spiked with the low level of each drug.

The matrix effect was evaluated through samples enriched with PPCPs at two concentration levels (low and high): $0.5 \mu \mathrm{g} / \mathrm{L}$ and $7.0 \mu \mathrm{g} / \mathrm{L}$, for waters and $120 \mathrm{ng} / \mathrm{g}$ and $280 \mathrm{ng} / \mathrm{g}$ for fish. Precision was measured to determine the variability of a series of independent test results obtained with the same sample by testing on the same day and different days, under conditions of intermediate precision in terms of repeatability (\% RSD). For the analyzes, 7 samples were used per analyst that contained all the two drugs at three concentration levels (low, medium, and high) $0.5,5.0$, and $10 \mu \mathrm{g} / \mathrm{L}$, for waters and 20, 160 , and $400 \mathrm{ng} / \mathrm{g}$ for fish. on 3 different days $(p=3)$ (Kruve et al. 2015a, 2015b; Magnusson and Örnemark 2014).

The uncertainty was associated with the result of a measurement that characterizes the dispersion of values that can be attributed to the measurement process (Joint Committee for Guides in Metrology 2008). To obtain the expanded uncertainty of measurement $(U)$, the combined standard uncertainties $(u)$ were multiplied by the coverage factor $\mathrm{K}=2$.

\subsection{Sample collection}

A duplicate collection of water samples and fish (P. magdaleniatum) samples was carried out. Fish were purchased in the marketplaces from each of the five water sampling sites of the Cauca (Ciénaga de Ayapel, Nechí, La Apartada, Caucasia, and Guarumo) and Magdalena rivers (Barrancabermeja, Puerto Berrío, Puerto Serviez, Puerto Triunfo, and La Dorada), Figure 1, during the years 2017-2019. It can be 
affirmed that the fish bought in the marketplaces correspond to the water sampling sites since the fishermen catch them near each sampling area; Also, this species does not present constant migrations, it only has 2 annual migrations associated with reproduction cycles (Mojica et al. 2012), however, the fish for this research were not caught in the migration season since there is a ban, which prohibits the sale, marketing, storage and consumption of this fish throughout the country (AUNAP and Minagricultura 2019).

Water and fish monitoring were conducted over two years and in three different climatic seasons; rainy, transition and dry. In Colombia, the climatic seasons are determined by the precipitation caused by the annual movement of the intertropical convergence zone (ITCZ), which presents rainy periods in MarchMay and September - November, and dry periods in June - August and December - February (Guzmán et al. 2014; Vélez et al. 2006), with dry-rain transition periods in February-March and August-September, and rain-dry transition in May-June and November-December.

In each sampling site, in situ measurements of water temperature, $\mathrm{pH}$, dissolved oxygen, oxygen saturation, and conductivity were taken using multiparametric equipment HACH HQ40d (Loveland, Colorado, United States) that had been previously calibrated in the laboratory. The water samples were collected in $500 \mathrm{~mL}$ amber glass bottles that had been previously muffled. Once the fish muscle tissue was purchased and the water samples were collected, they were transported in a cooler with ice to the Pollution Diagnostics and Control Laboratory, University of Antioquia, Colombia. The water samples were kept in the refrigerator $\left(4-6^{\circ} \mathrm{C}\right)$ and the muscle tissue samples were homogenized with an industrial processor and immediately frozen $\left(\leq-20^{\circ} \mathrm{C}\right)$ until analysis.

\subsection{Sample preparation}

\subsubsection{Muscle tissue}

For analysis, the samples were thawed and $5.0 \mathrm{~g}$ of the homogenized fish was weighed in a $50 \mathrm{~mL}$ Falcon ${ }^{\circledR}$ tube, followed by $5 \mathrm{~mL}$ of acidified water $(\mathrm{pH}=2.0 \mathrm{HCl})$ so that the mixture was homogeneous. The Ultra Turrax was used at the maximum level. After homogenization, $10 \mathrm{ml}$ of acetonitrile, and Original QuEChERS were added. The samples were vigorously mixed for 1 minute and subsequently centrifuged at $5000 \mathrm{rpm}(3864 \mathrm{~g})$ for 5 minutes. The samples were frozen for one hour, after which $500 \mu \mathrm{L}$ of the supernatant was taken, and $500 \mu \mathrm{L}$ of $\mathrm{H} 2 \mathrm{O}: \mathrm{MeOH}(90: 10 \mathrm{v} / \mathrm{v})$ was added for further analysis by UHPLCMS/MS.

\subsubsection{Water}

The water samples were taken from cooling $\left(4-6^{\circ} \mathrm{C}\right)$ to room temperature $\left(\approx 24^{\circ} \mathrm{C}\right)$ as the samples possibly had suspended solids. $50 \mathrm{~mL}$ of sample was taken and diluted with ultrapure water until reaching a volume of $200 \mathrm{~mL}$ (1: 4). The samples were filtered with glass wool, adjusted to $\mathrm{pH}=2$ with $\mathrm{HCl}$ and the internal standards (Diclofenac-d4 and Ibuprofen ${ }^{13} \mathrm{C}_{6}$ ) were added. The cartridges used for SolidPhase Extraction (SPE) were OASIS HLB (3 ccs, 60 mg) from Waters (Milford, Massachusets, USA), which 
were conditioned with $12 \mathrm{~mL}$ of $\mathrm{MeOH}$ and $3 \mathrm{~mL}$ of ultrapure water at Visiprep ${ }^{\mathrm{TM}}$ SPE Vacuum Manifold system from SUPLECO (Darmstadt, Germany). Then, $3 \mathrm{~mL}$ of $\mathrm{H}_{2} \mathrm{O}$ at $\mathrm{pH}=2$ was added, the samples were passed at a flow rate of $5-10 \mathrm{~mL} / \mathrm{min}$ and rinsed with $10 \mathrm{~mL}$ of ultrapure water, and the cartridges were allowed to dry under vacuum for 5 minutes. Analytes were eluted in glass tubes with $12 \mathrm{~mL}$ of $\mathrm{MeOH}$. Extracts were concentrated to approximately $1 \mathrm{~mL}$ under nitrogen stream with the Visidry ${ }^{\mathrm{TM}}$ Drying Attachment system from SUPELCO (Darmstadt, Germany), reconstituted in $5 \mathrm{~mL}$ volumetric balloon with $\mathrm{H} 2 \mathrm{O}: \mathrm{MeOH}(90: 10 \mathrm{v} / \mathrm{v})$ and analyzed immediately by UHPLC-MS/MS.

\subsection{Statistical analysis}

Statistical analysis was performed using Statgraphics Centurion XVII. The evaluation of the normality of the continuous variables was performed using the Shapiro-Wilk test. An analysis of variance (ANOVA) was used to evaluate the existence of significant differences between the sampling sites and the climatic seasons. Afterward, the honestly significant difference test (Tukey's HSD) was performed. For all statistical analyzes, the significance criterion was established at $\mathrm{p}<0.05$.

\section{Results}

The results of the physicochemical variables taken in situ are presented in Figure 2. For all the parameters measured in the field, there were no statistically significant differences by season, although differences were found in some of the sampling sites. The highest temperatures were recorded in Barrancabermeja $\left(28.76 \pm 0.35^{\circ} \mathrm{C}\right)$, Nechí $\left(28.51 \pm 0.66^{\circ} \mathrm{C}\right)$, and Ciénaga Ayapel $\left(31.02 \pm 1.33^{\circ} \mathrm{C}\right)$. The pH had statistically significant differences $(p<0.05)$, with a range between 6.91-7.69. Dissolved oxygen showed statistical differences $(p<0.05)$ at the Barrancabermeja $(5.42 \pm 0.34 \mathrm{mg} / \mathrm{L})$, La Dorada $(5.52 \pm 0.29$ $\mathrm{mg} / \mathrm{L})$, Caucasia $(6.56 \pm 0.49 \mathrm{mg} / \mathrm{L})$, Nechí $(6.92 \pm 0.21 \mathrm{mg} / \mathrm{L})$, and Guarumo $(7.13 \pm 0.03 \mathrm{mg} / \mathrm{L})$ sites. Finally, there was no statistically significant difference $(p<0.05)$ for conductivity, which remained in the range of $68.9-239.109 \mu \mathrm{S} / \mathrm{cm}$.

Generally, appropriate conditions for striped catfish farming are a pH range of 6.5 to 8.5 (Augusto and Millán 2003; Tucker 1991); a minimum temperature of $23^{\circ} \mathrm{C}$ (Augusto and Millán 2003) and an optimum range of 26 to $28^{\circ} \mathrm{C}$ [33]; and an OD from $3 \mathrm{mg} / \mathrm{L}$ to $12 \mathrm{mg} / \mathrm{L}$ at most (Augusto and Millán 2003; Imasd 2007).

The levels of ibuprofen and diclofenac in the waters of the Cauca and Magdalena rivers for each climatic season are presented in Table 6. In general, for all sampling sites and all climatic seasons, ibuprofen was always below the limit of quantification $(0.50 \mu \mathrm{g} / \mathrm{L})$. Diclofenac was below the limit of quantification in most of the sites, however, in three sites of the Cauca River, levels from $12.20 \mu \mathrm{g} / \mathrm{L}$ to $75.04 \mu \mathrm{g} / \mathrm{L}$ were presented in the dry season. Meanwhile, in the Magdalena River, three sampling sites had diclofenac concentrations in a range of $0.68-7.35 \mu \mathrm{g} / \mathrm{L}$ in the transition period. After performing a single variance analysis per sample site, on average for all samples the highest diclofenac concentration was found in Nechí. 
Table 7 presents the results for ibuprofen and diclofenac analyzed in $P$. magdaleniatum at the different sampling sites and by climatic season. For all sampling sites, in all climatic seasons, the concentrations of ibuprofen in catfish were below the limit of detection $(5.0 \mathrm{ng} / \mathrm{g})$, as were the concentrations of diclofenac (limit of detection $20.0 \mathrm{ng} / \mathrm{g}$ ). Some samples were above the limit of detection, but could not be quantified with precision and accuracy.

\section{Discussion}

Although the presence and distribution of most pharmaceutical products in the world are well documented, there is still a lack of information on the presence of pharmaceutical products such as diclofenac and ibuprofen in Latin America. This information is important because most of the countries in this region make direct discharges into rivers, lakes, and reservoirs, where water is not only in contact with aquatic biota but is also used for human consumption (Botero-Coy et al. 2018). This is the case in Colombia, which does not have enough wastewater treatment plants, and most of those that exist do not have advanced processes for the elimination of certain types of compounds (Arias and Brown 2009; Botero-Coy et al. 2018).

In this study, it was possible to verify that there is no presence of ibuprofen and diclofenac in any of the muscle tissue samples of striped catfish $P$. magdaleniatum while, on the other hand, concentrations for diclofenac were found in the water of both the Cauca and Magdalena rivers $(0.68-75.04 \mu \mathrm{g} / \mathrm{L})$. The highest concentrations of this drug were found in the dry season, where there is possibly a higher concentration of diclofenac due to the decrease of the water column in the rivers. (Andrade-Sossa et al. 2011; Huang et al. 2011; Sathishkumar et al. 2020). These same dry season patterns have been reported in surface waters in the United States and South Korea (Huang et al. 2011). In some cases like this, the concentrations of contaminants in the fish muscle do not reflect the concentrations present in the water where they live. As evidenced in this study, for the dry season and certain sampling sites, detectable concentrations of diclofenac were present, but concentrations of this drug were not detected in catfish muscle during the two years of sampling; active diclofenac is a hydrophilic compound with a Log Kow = 1.90 (Scheytt et al. 2005), which makes it difficult for it to accumulate in this type of tissue.

Recent studies conducted in Colombia on urban wastewater from the Bogotá and Medellín rivers showed diclofenac levels of $0.40 \mu \mathrm{g} / \mathrm{L}$ for the Bogotá river and $0.24 \mu \mathrm{g} / \mathrm{L}$ for the Medellín river (Botero-Coy et al. 2018), concentrations were lower than those found in this study because the Bogotá and Medellín rivers are tributaries of the Magdalena and Cauca rivers (Roldán Pérez and Ramírez Restrepo 2008; Suárez G 2002). Some pharmaceutical products are present and constant in the rivers of Colombia. As shown in Table 8, countries such as Mexico, Nigeria, and South Africa present diclofenac concentrations between $1.4 \mu \mathrm{g} / \mathrm{L}$ and $57.16 \mu \mathrm{g} / \mathrm{L}$, similar to those of the present study, although the concentrations in this study are the highest reported so far. The higher concentrations of diclofenac in rivers may be a result of discharges from urbanized areas or rural areas with intense agricultural activity. (Sathishkumar et al. 2020). 
As shown in Table 8, ibuprofen is present in waters in different parts of the world, with particularly striking results from studies in China, Spain, South Africa, Romania, and the United Kingdom, which show concentrations ranging from 2. $4 \mathrm{ng} / \mathrm{L}$ (Wang et al. 2010) to $3086 \mathrm{ng} / \mathrm{L}$ (Ebele et al. 2017). However, it is not possible to express whether these values are high or low because no maximum levels of this type of compound in the water have been defined so far since they have not yet been included in the list of substances for Union-wide monitoring in the field of water policy according to Directive 2008/105/EC (European Commission 2018). Moreover, the conditions that these drugs can have in water for human consumption, as well as their interactions with the aquatic ecosystem, are not known (Botero-Coy et al. 2018).

Ibuprofen can be susceptible to direct photochemical degradation and different indirect pathways, such as reactions with singlet oxygen, hydroxyl radicals, peroxide radicals, and photoexcited organic matter, among others (Packer et al. 2003). Therefore, the present study is not able to quantify levels for ibuprofen, because the previously mentioned photochemical processes are accentuated in places where there is greater solar exposure, such as the rivers studied in this work, but this does not imply that this drug is not present in the two rivers studied.

\section{Conclusions}

The results of this study show that some drugs such as diclofenac may be present in the test waters. The Cauca and Magdalena rivers are the recipients of the waters of Colombia; therefore, the sampling sites are points of high contamination, which receive the direct discharges of wastewater. For this study, concentrations of diclofenac were detected for the transition season of 0.500-7.32 $\mu \mathrm{g} \mathrm{L}$, and in dry season $0.500-75.042 \mu \mathrm{g} / \mathrm{L}$ in surface water, it is important to note that these diclofenac results are the highest reported up to date. On the other hand, no ibuprofen concentrations were found in the water samples analyzed for any site or weather season.

On the other hand, neither ibuprofen nor diclofenac concentrations were detected in the muscle tissue of $P$. magdaleniatum. Likely, they were not found directly in the muscle, since this reflects more chronic exposures; for future research, it is intended to carry out analyzes in other parts of the body, liver, or kidneys, which may indicate recent exposures to this type of contaminant. This study is one of the first to analyze different points along the main rivers of Colombia, which gives an idea of the degree of contamination of ibuprofen and diclofenac both in water and in this endemic fish in the region.

For future studies, it is intended to carry out a higher concentration factor in the extraction of the samples, to detect and quantify both drugs, as well as the analysis of the metabolites to give more information on the exposure and the inclusion of other tissues for the analysis.

\section{Declarations}

\section{Acknowledgments}


To the Ministry of Science, Technology, and Innovation of Colombia, for the financing of project code 111569944244 , contract FP 44842 No. 223 of 2015. The GDCON group of the University of Antioquia is also thanked for their part in funding the project.

\section{References}

Afonso-Olivares, C., Sosa-Ferrera, Z., \& Santana-Rodríguez, J. J. (2017). Occurrence and environmental impact of pharmaceutical residues from conventional and natural wastewater treatment plants in Gran Canaria (Spain). Science of the Total Environment, 599-600, 934-943.

doi:10.1016/j.scitotenv.2017.05.058

Ali, A. M., Rønning, H. T., Sydnes, L. K., Alarif, W. M., Kallenborn, R., \& Al-Lihaibi, S. S. (2018). Detection of PPCPs in marine organisms from contaminated coastal waters of the Saudi Red Sea. Science of the Total Environment, 621, 654-662. doi:10.1016/j.scitotenv.2017.11.298

Andrade-Sossa, C., García-Folleco, M., Rodríguez-Munar, C. A., Duque, S. R., \& Realpe, E. (2011). Effects of water level fluctuation on rotifers assemblage structure in Largo lake (Yahuarcaca sistem - river Amazon floodplain - Colombia). Caldasia, 33(2).

https://revistas.unal.edu.co/index.php/cal/article/view/36412/38106

AOAC Official Methods of Analysis. (2016). Appendix F: Guidelines for Standard Method Performance Requirements. Rockville, USA. http://www.eoma.aoac.org/app_f.pdf

Arias, M. E., \& Brown, M. T. (2009). Feasibility of using constructed treatment wetlands for municipal wastewater treatment in the Bogotá Savannah, Colombia. Ecological Engineering, 35(7), 1070-1078. doi:10.1016/j.ecoleng.2009.03.017

Augusto, G., \& Millán, C. (2003). Guía para el manejo, cría y conservación del bagre rayado: Pseudoplatystoma fasciatum (Linneo). (Convenio Andrés Bello, Ed.). Bogotá. https://www.academia.edu/17458383/Guia_Cultivo_bagre_rayado?auto=download

AUNAP, \& Minagricultura. Resolución 805 de 26 de Abril 2019 (2019). Bogotá (Colombia).

Botero-Coy, A. M., Martínez-Pachón, D., Boix, C., Rincón, R. J., Castillo, N., Arias-Marín, L. P., et al. (2018). An investigation into the occurrence and removal of pharmaceuticals in Colombian wastewater. Science of the Total Environment, 642, 842-853. doi:10.1016/j.scitotenv.2018.06.088

Brozinski, J. M., Lahti, M., Meierjohann, A., Oikari, A., \& Kronberg, L. (2013). The anti-inflammatory drugs diclofenac, naproxen and ibuprofen are found in the bile of wild fish caught downstream of a wastewater treatment plant. Environmental Science and Technology, 47(1), 342-348. doi:10.1021/es303013j

Budiman, H., \& Zuas, O. (2017). Trace Measurement Of CO, CH4, And CO2 in High Purity Gases by GC-FidMethanizer: Method Validation and Uncertainty Estimation. Scientific Study \& Research, 18(3), 259-274. 
Chen, J.-B., Gao, H.-W., Zhang, Y.-L., Zhang, Y., Zhou, X.-F., Li, C.-Q., \& Gao, H.-P. (2014). Developmental Toxicity of Diclofenac and Elucidation of Gene Regulation in zebrafish (Danio rerio). Scientific reports, 4, 4841. doi:10.1038/srep04841

De La Hoz-M, J., J.C. Narváez, L., Manjarrés-Martínez, L., Nieto A, L., Rivera, R., Cuello, F., \& Álvarez, T. (2014a). Boletín Estadístico Noviembre - Diciembre de 2014. Bogotá (Colombia).

http://sepec.aunap.gov.co/Home/VerPdf/19

De La Hoz-M, J., J.C. Narváez, L., Manjarrés-Martínez, L., Nieto A, L., Rivera, R., Cuello, F., \& Álvarez, T. (2014b). Boletín Estadístico Enero - Junio de 2014. (Autoridad Nacional de Acuicultura y Pesca (AUNAP), Ed.). Bogotá (Colombia). http://sepec.aunap.gov.co/Home/VerPdf/18

Duarte, I. A., Reis-Santos, P., Novais, S. C., Rato, L. D., Lemos, M. F. L., Freitas, A., et al. (2020). Depressed, hypertense and sore: Long-term effects of fluoxetine, propranolol and diclofenac exposure in a top predator fish. Science of the Total Environment, 712. doi:10.1016/j.scitotenv.2020.136564

Ebele, A. J., Abou-Elwafa Abdallah, M., \& Harrad, S. (2017). Pharmaceuticals and personal care products (PPCPs) in the freshwater aquatic environment. Emerging Contaminants, (2016).

doi:10.1016/j.emcon.2016.12.004

Environmental Protection Agency (EPA), Office of Water, Office of Science and Technology, \& Engineering and Analysis Division. (2007). Method 1694: Pharmaceuticals and Personal Care Products in Water, Soil, Sediment, and Biosolids by HPLC/MS/MS. US EPA. https://www.epa.gov/sites/production/files/201510/documents/method_1694_2007.pdf

Eurachem / CITAC. (2015). Setting and Using Target Uncertainty in Chemical Measurement. (R. Bettencourt da Silva \& A. Williams, Eds.) (First.). doi:10.13140/RG.2.1.1463.9446

EURACHEM / CITAC. (2012). Quantifying Uncertainty in Analytical Measurement, Guide CG 4. (S. L. R. Ellison \& A. Williams, Eds.) (Third.). doi:0 948926155

European Commission. European Commission Implementation Decision 2015/495/EC establishing a watch list of substances for Union-wide monitoring in the field of water policy pursuant to Directive 2008/105/EC of the European Parliament and of the Council. , Official Journal of the European Union L78/40 (2015). doi:http://eur-lex.europa.eu/pri/en/oj/dat/2003/I_285/I_28520031101en00330037.pdf

European Commission. (2018). European Commission Implementation Decision 2018/840 establishing a watch list of substances for Union-wide monitoring in the field of water policy pursuant to Directive 2008/105/EC of the European Parliament and of the Council and repealing Commission Im. Official Journal of the European Union, 61(9-12), L 141/9.

García Gómez, C., Gortáres Moroyoqui, P., \& Drogui, P. (2011). Contaminantes emergentes: efectos y tratamientos de remoción. Revista Química Viva, (2), 96-105. 
Garcia, S. M., Zerbi, A., Aliaume, C., Do Chi, T., \& Lasserre, G. (2003). The ecosystem approach to fisheries. FAO Fisheries Technical Paper(Vol. 443). doi:10.1111/j.1467-2979.2010.00358.x

Gonzalez-Rey, M., \& Bebianno, M. J. (2012). Does non-steroidal anti-inflammatory (NSAID) ibuprofen induce antioxidant stress and endocrine disruption in mussel Mytilus galloprovincialis? Environmental Toxicology and Pharmacology, 33(2), 361-371. doi:10.1016/j.etap.2011.12.017

González, J., Landines, M. A., Borbón, J., Correal, M. L., \& Sánchez, C. (2014). Evaluación de algunos marcadores de exposición a contaminantes en tres especies de bagres colombianos (Pisces:Siluriformes). Biota Colombiana, 15(1), 7-14.

Goyenola, G. (2007). Dissolved oxygen. RED MAPSA. http://imasd.fcien.edu.uy/difusion/educamb/propuestas/red/curso_2007/cartillas/tematicas/OD.pdf Guiloski, I. C., Ribas, J. L. C., Pereira, L. da S., Neves, A. P. P., \& Silva de Assis, H. C. (2015). Effects of trophic exposure to dexamethasone and diclofenac in freshwater fish. Ecotoxicology and Environmental Safety, 114, 204-211. doi:10.1016/j.ecoenv.2014.11.020

Gutiérrez-Noya, V. M., Gómez-Oliván, L. M., Ramírez-Montero, M. del C., Islas-Flores, H., Galar-Martínez, M., Dublán-García, O., \& Romero, R. (2020). Ibuprofen at environmentally relevant concentrations alters embryonic development, induces teratogenesis and oxidative stress in Cyprinus carpio. Science of the Total Environment, 710, 136327. doi:10.1016/j.scitotenv.2019.136327

Guzmán, D., Ruíz, J. F., \& Cadena, M. (2014). Regionalización de colombia según la estacionalidad de la precipitación media mensual, a través análisis de componentes principales (ACP). (Grupo de Modelamiento de Tiempo Clima y Escenarios de Cambio Climático \& Subdirección de Meteorología IDEAM, Eds.) (Vol. 85). doi:10.1016/j.bbapap.2013.06.007

Han, S., Choi, K., Kim, J., Ji, K., Kim, S., Ahn, B., et al. (2010). Endocrine disruption and consequences of chronic exposure to ibuprofen in Japanese medaka (Oryzias latipes) and freshwater cladocerans Daphnia magna and Moina macrocopa. Aquatic Toxicology, 98(3), 256-264.

doi:10.1016/j.aquatox.2010.02.013

Herrera-Cruz, E., Aristizabal-Regino, J., Yepes-Blandón, J., Estrada-Posada, A., Espinosa-Araujo, J., \& Atencio-Garcia, V. (2019). Evaluation of three cryoprotectants to preserve striped catfish ( Pseudoplatystoma magdaleniatum ) semen. Rev. Colomb. Biotecnol, XXI, 55-62. doi:10.15446/rev.colomb.biote.v21n2.77847

Huang, Q., Yu, Y., Tang, C., Zhang, K., Cui, J., \& Peng, X. (2011). Occurrence and behavior of non-steroidal anti-inflammatory drugs and lipid regulators in wastewater and urban river water of the Pearl River Delta, South China. Journal of Environmental Monitoring, 13(4), 855-863. doi:10.1039/c1em10015g 
Imasd. (2007). Oxígeno Disuelto. Red de Monitoreo Ambiental Participativo de Sistemas Acuáticos. doi:10.1016/0004-6981(80)90167-5

Joint Committee for Guides in Metrology. (2008). Evaluation of measurement data - Guide to the expression of uncertainty in measurement (First edit.). doi:10.1373/clinchem.2003.030528

Kasprzyk-Hordern, B., Dinsdale, R. M., \& Guwy, A. J. (2009). The removal of pharmaceuticals, personal care products, endocrine disruptors and illicit drugs during wastewater treatment and its impact on the quality of receiving waters. Water Research, 43(2), 363-380. doi:10.1016/j.watres.2008.10.047

Kraak, V. Der. (2002). Wildlife. In IPCS Global Assessment of EDCs (p. 18).

Kruve, A., Rebane, R., Kipper, K., Oldekop, M. L., Evard, H., Herodes, K., et al. (2015a). Tutorial review on validation of liquid chromatography-mass spectrometry methods: Part I. Analytica Chimica Acta, 870(1), 29-44. doi:10.1016/j.aca.2015.02.017

Kruve, A., Rebane, R., Kipper, K., Oldekop, M. L., Evard, H., Herodes, K., et al. (2015b). Tutorial review on validation of liquid chromatography-mass spectrometry methods: Part II. Analytica Chimica Acta, 870(1), 8-28. doi:10.1016/j.aca.2015.02.016

Liu, J., Lu, G., Xie, Z., Zhang, Z., Li, S., \& Yan, Z. (2015). Occurrence, bioaccumulation and risk assessment of lipophilic pharmaceutically active compounds in the downstream rivers of sewage treatment plants. Science of the Total Environment, 511, 54-62. doi:10.1016/j.scitotenv.2014.12.033

Magnusson, B., \& Örnemark, U. (2014). Eurachem Guide: The Fitness for Purpose of Analytical Methods A Laboratory Guide to Method Validation and Related Topics (2nd ed.). doi:10.1016/S00142999(99)00500-2

Mathias, F. T., Fockink, D. H., Disner, G. R., Prodocimo, V., Ribas, J. L. C., Ramos, L. P., et al. (2018). Effects of low concentrations of ibuprofen on freshwater fish Rhamdia quelen. Environmental Toxicology and Pharmacology, 59(March), 105-113. doi:10.1016/j.etap.2018.03.008

Mavropoulou, A. M., Vervatis, V., \& Sofianos, S. (2020). Dissolved oxygen variability in the Mediterranean Sea. Journal of Marine Systems, 208(May 2019). doi:10.1016/j.jmarsys.2020.103348

Meador, J. P., Yeh, A., Young, G., \& Gallagher, E. P. (2016). Contaminants of emerging concern in a large temperate estuary. Environmental Pollution, 213, 254-267.

Memmert, U., Peither, A., Burri, R., Weber, K., Schmidt, T., Sumpter, J. P., \& Hartmann, A. (2013). Diclofenac: New data on chronic toxicity and bioconcentration in fish. Environmental Toxicology and Chemistry, 32(2), 442-452. doi:10.1002/etc. 2085

Mojica, J., Usma, J., Álvarez, R., \& Lasso, C. A. (2012). Libro rojo de peces dulceacuícolas de Colombia 2012. Instituto de Investigación de Recursos Biológicos Alexander von Humboldt Instituto de Ciencias 
Naturales de la Universidad Nacional de Colombia WWF Colombia Universidad de Manizales. Bogotá (Colombia). doi:10.1017/CB09781107415324.004

Mojica, J., Valderrama, M., Jimenez-Segura, L., \& Alonso, J. C. (2016). Pseudoplatystoma magdaleniatum. The IUCN Red List of Threatened Species. International Union for Conservation of Nature and Natural Resources. http://dx.doi.org/10.2305/IUCN.UK.2016-1.RLTS.T58439165A61474168.en

Mottaleb, M. A., Bellamy, M. K., Mottaleb, M. A., \& Islam, M. R. (2015). Use of LC-MS and GC-MS Methods to Measure Emerging Contaminants Pharmaceutical and Personal Care Products (PPCPs) in Fish. Journal of Chromatography \& Separation Techniques, 6(3), 2-9.

Naidu, R., Arias Espana, V. A., Liu, Y., \& Jit, J. (2016). Emerging contaminants in the environment: Riskbased analysis for better management. Chemosphere, 154, 350-357.

doi:10.1016/j.chemosphere.2016.03.068

Nallani, G. C., Paulos, P. M., Constantine, L. A., Venables, B. J., \& Huggett, D. B. (2011). Bioconcentration of ibuprofen in fathead minnow (Pimephales promelas) and channel catfish (Ictalurus punctatus). Chemosphere, 84(10), 1371-1377. doi:10.1016/j.chemosphere.2011.05.008

Official Journal of the European Communities. Directive 96/23/EC concerning the performance of analytical methods and the interpretation of results (notified under document number C(2002) 3044)(Text withEEA relevance) (2002/657/EC) (2002). doi:10.1017/CB09781107415324.004

Ojemaye, C. Y., \& Petrik, L. (2019). Occurrences, levels and risk assessment studies of emerging pollutants (pharmaceuticals, perfluoroalkyl and endocrine disrupting compounds) in fish samples from Kalk Bay harbour, South Africa. Environmental Pollution, 252, 562-572. doi:10.1016/j.envpol.2019.05.091

Packer, J. L., Werner, J. J., Latch, D. E., McNeill, K., \& Arnold, W. A. (2003). Photochemical fate of pharmaceuticals in the environment: Naproxen, diclofenac, clofibric acid, and ibuprofen. Aquatic Sciences, 65(4), 342-351. doi:10.1007/s00027-003-0671-8

Paíga, P., Lolic, A., Hellebuyck, F., Santos, L. H. M. L. M., Correia, M., \& Delerue-Matos, C. (2015). Development of a SPE-UHPLC-MS/MS methodology for the determination of non-steroidal antiinflammatory and analgesic pharmaceuticals in seawater. Journal of Pharmaceutical and Biomedical Analysis, 106, 61-70. doi:10.1016/j.jpba.2014.06.017

Pal, A., He, Y., Jekel, M., Reinhard, M., \& Gin, K. Y. H. (2014). Emerging contaminants of public health significance as water quality indicator compounds in the urban water cycle. Environment International, $71,46-62$.

Peña Álvarez, A., \& Castillo Alanís, A. (2015). Identificación y cuantificación de contaminantes emergentes en aguas residuales por microextracción en fase sólida-cromatografía de gases- 
espectrometría de masas (MEFS-CG-EM). Tip Revista Especializada en Ciencias Químico-Biológicas, 18(1), 29-42.

Petrie, B., Barden, R., \& Kasprzyk Hordern, B. (2014). A review on emerging contaminants in wastewaters and the environment: Current knowledge, understudied areas and recommendations for future monitoring. Water Research, 72, 3-27.

Petrović, M., Škrbić, B., Živančev, J., Ferrando-Climent, L., \& Barcelo, D. (2014). Determination of 81 pharmaceutical drugs by high performance liquid chromatography coupled to mass spectrometry with hybrid triple quadrupole-linear ion trap in different types of water in Serbia. Science of the Total Environment, 468-469, 415-428. doi:10.1016/j.scitotenv.2013.08.079

Rocco, L., Frenzilli, G., Fusco, D., Peluso, C., \& Stingo, V. (2010). Evaluation of zebrafish DNA integrity after exposure to pharmacological agents present in aquatic environments. Ecotoxicology and Environmental Safety, 73(7), 1530-1536. doi:10.1016/j.ecoenv.2010.07.032

Roldán Pérez, G., \& Ramírez Restrepo, J. J. (2008). Fundamentos de limnología neotropical. (Universidad de Antioquia, Ed.) (llustrada.). Medllin.

Romano Mozo, D. (2012). Disruptores endocrinos Nuevas respuestas para nuevos retos. (Instituto Sindical de Trabajo Ambiente y Salud (ISTAS), Ed.). Madrid, Spain. https://noharmuscanada.org/documentos/americalatina/disruptores-endocrinos-nuevas-respuestas-para-nuevos-retos

Saravanan, M., Devi, K. U., Malarvizhi, A., \& Ramesh, M. (2012). Effects of Ibuprofen on hematological, biochemical and enzymological parameters of blood in an Indian major carp, Cirrhinus mrigala. Environmental Toxicology and Pharmacology, 34(1), 14-22. doi:10.1016/j.etap.2012.02.005

Sathishkumar, P., Meena, R. A. A., Palanisami, T., Ashokkumar, V., Palvannan, T., \& Gu, F. L. (2020). Occurrence, interactive effects and ecological risk of diclofenac in environmental compartments and biota - a review. Science of the Total Environment, 698, 134057. doi:10.1016/j.scitotenv.2019.134057

Scheytt, T., Mersmann, P., Lindstädt, R., \& Heberer, T. (2005). 1-Octanol/water partition coefficients of 5 pharmaceuticals from human medical care: Carbamazepine, clofibric acid, diclofenac, ibuprofen, and propyphenazone. Water, Air, and Soil Pollution, 165(1-4), 3-11. doi:10.1007/s11270-005-3539-9

Schmidt, W., O'Rourke, K., Hernan, R., \& Quinn, B. (2011). Effects of the pharmaceuticals gemfibrozil and diclofenac on the marine mussel (Mytilus spp.) and their comparison with standardized toxicity tests. Marine Pollution Bulletin, 62(7), 1389-1395. doi:10.1016/j.marpolbul.2011.04.043

Schwaiger, J., Ferling, H., Mallow, U., Wintermayr, H., \& Negele, R. D. (2004). Toxic effects of the nonsteroidal anti-inflammatory drug diclofenac. Part I: Histopathological alterations and bioaccumulation in rainbow trout. Aquatic Toxicology, 68(2), 141-150. doi:10.1016/j.aquatox.2004.03.014 
Stancova, V., Plhalova, L., Blahova, J., Zivna, D., Bartoskova, M., Siroka, Z., et al. (2017). Effects of the pharmaceutical contaminants ibuprofen, diclofenac, and carbamazepine alone, and in combination, on oxidative stress parameters in early life stages of tench (Tinca tinca). Original Paper Veterinarni Medicina, 62(02), 90-97. doi:10.17221/125/2016-VETMED

Suárez G, C. A. (2002). Colombia Andina. (Editorial Norma, Ed.).

Tucker, C. S. (1991). Water Quantity and Quality Requirements for Channel Catfish Hatcheries. Southern Regional Aquaculture Center Factsheet, Publicatio(461), 8.

Vandermeersch, G., Lourenço, H. M., Alvarez Muñoz, D., Cunha, S., Diogène, J., Cano Sancho, G., et al. (2015). Environmental contaminants of emerging concern in seafood - European database on contaminant levels. Environmental Research, 143, 29-45.

Vélez, M. I., Hooghiemstra, H., Metcalfe, S., Wille, M., \& Berrío, J. C. (2006). Late Glacial and Holocene environmental and climatic changes from a limnological transect through Colombia, northern South America. Palaeogeography, Palaeoclimatology, Palaeoecology, 234(1), 81-96.

doi:10.1016/j.palaeo.2005.10.020

Vianneth, M., \& Roa, S. (2013). Condición de venta de analgésicos antiinflamatorios no esteroides, legalmente autorizados para su comercialización en Colombia . Estrategias de uso racional Resumen Condition of sale of non-steroidal anti-inflammatory drugs Introducción. Revista Colombiana de Ciencias Químico-Farmacéuticas, 42(2), 145-168.

Wabaidur, S. M., AlOthman, Z. A., Siddiqui, M. R., Mohsin, K., Bousiakou, L. G., \& Karikas, G. A. (2015). UPLC-MS method for the simultaneous determination of naproxen, fluvastatin and ibuprofen in waste water samples. Journal of Industrial and Engineering Chemistry, 24, 302-307.

doi:10.1016/j.jiec.2014.09.046

Wang, L., Ying, G. G., Zhao, J. L., Yang, X. B., Chen, F., Tao, R., et al. (2010). Occurrence and risk assessment of acidic pharmaceuticals in the Yellow River, Hai River and Liao River of north China. Science of the Total Environment, 408(16), 3139-3147. doi:10.1016/j.scitotenv.2010.04.047

WHO Technical Report Series. (2019). The selection and use of essential medicines: report of the WHO Expert Committee on Selection and Use of Essential Medicines, 2019 (including the 21st WHO Model List of Essential Medicines and the 7th WHO Model List of Essential Medicines for Children). Geneva: World Health Organization. WHO Press.

Zhang, K., Yuan, G., Werdich, A. A., \& Zhao, Y. (2020). Ibuprofen and diclofenac impair the cardiovascular development of zebrafish (Danio rerio) at low concentrations. Environmental Pollution, 258, 113613. doi:10.1016/j.envpol.2019.113613

\section{Tables}


Table 1. Feature of standards and isotopically labeled standards.

\begin{tabular}{|c|c|c|c|c|c|}
\hline Group & $\begin{array}{l}\text { CAS } \\
\text { number }\end{array}$ & Molecule & $\begin{array}{l}\text { Corresponding internal } \\
\text { standard }\end{array}$ & $\begin{array}{l}\text { CAS } \\
\text { number }\end{array}$ & Molecule \\
\hline \multirow[t]{3}{*}{ NSAIDs } & $\begin{array}{l}15687- \\
27-1\end{array}$ & $\begin{array}{l}\mathrm{C}_{13} \mathrm{H}_{18} \mathrm{O}_{2} \\
\text { Ibuprofen }\end{array}$ & Ibuprofen- $-{ }^{13} \mathrm{C}_{6}$ & $\begin{array}{l}1216459- \\
54-9\end{array}$ & $\mathrm{C} \square[\mathrm{C} \square \mathrm{H} \square \mathrm{O} \square$ \\
\hline & $\begin{array}{l}15307- \\
79-6\end{array}$ & & Diclofenc- $d_{4}$ & $\begin{array}{l}153466- \\
65-0\end{array}$ & 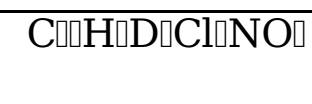 \\
\hline & & $\begin{array}{l}\mathrm{C}_{14} \mathrm{H}_{10} \mathrm{Cl}_{2} \\
\text { Diclofena } \\
\text { Sodium }\end{array}$ & & & \\
\hline
\end{tabular}

Table 2. The gradient in mobile phases A and B

\begin{tabular}{cccc}
\hline Time $(\mathrm{min})$ & Flow & $\mathrm{A}$ & $\mathrm{B}$ \\
\hline 0.0 & 0.30 & 90 & 10 \\
0.5 & 0.30 & 90 & 10 \\
3.0 & 0.30 & 0 & 100 \\
4.5 & 0.30 & 0 & 100 \\
4.6 & 0.30 & 90 & 10 \\
7.0 & 0.30 & 90 & 10 \\
\hline
\end{tabular}

Table 3. UHPLC-MS/MS condition

\begin{tabular}{lccccccc}
\hline Compound & Transition & $\begin{array}{c}\text { Precursor } \\
\text { ion } \\
(\mathrm{m} / \mathrm{z})\end{array}$ & $\begin{array}{c}\text { Retention } \\
\text { time } \\
(\mathrm{min})\end{array}$ & $\begin{array}{c}\text { Cone } \\
\text { voltage } \\
(\mathrm{V})\end{array}$ & $\begin{array}{c}\text { Collision } \\
\text { energy } \\
(\mathrm{ev})\end{array}$ & $\begin{array}{c}\text { Ionization } \\
\text { mode }\end{array}$ & $\begin{array}{c}\text { Ion } \\
\text { ratios }\end{array}$ \\
\hline Ibuprofen & $1(\mathrm{Q})$ & $\begin{array}{c}205.12> \\
161.1\end{array}$ & 4.04 & 20 & 5 & ESI- & N. A \\
\cline { 2 - 8 } Diclofenac & $1(\mathrm{Q})$ & $\begin{array}{c}294.10> \\
249.98\end{array}$ & 3.99 & 20 & 10 & ESI- & N. A \\
& 2 (q1) & $\begin{array}{c}295.81> \\
252\end{array}$ & 3.99 & 20 & 10 & ESI- & $\begin{array}{c}1.46 \\
(\mathrm{Q} / \mathrm{q} 1)\end{array}$ \\
\hline
\end{tabular}

Q: quantification transition, q1 confirmation transitions.

N.A: not applicable.

Table 4. Validation parameters of the analytical method for water samples. 


\begin{tabular}{|c|c|c|c|c|c|c|}
\hline Parameter & \multicolumn{3}{|c|}{ Ibuprofen } & \multicolumn{3}{|c|}{ Diclofenac } \\
\hline \multicolumn{7}{|l|}{ Selectivity $(\mathrm{n}=20)$} \\
\hline$\alpha \pm \mathrm{SD}, \% \mathrm{RSD}$ & \multirow{2}{*}{\multicolumn{6}{|c|}{$1.013 \pm 0.003 ; 0.268$}} \\
\hline Resolution $(\mathrm{n}=20)$ & & & & & & \\
\hline $\mathrm{R}_{\mathrm{s}} \pm \mathrm{SD}, \% \mathrm{RSD}$ & \multicolumn{6}{|c|}{$5.057 \pm 0.078 ; 7.48$} \\
\hline \multicolumn{7}{|l|}{ Linearity $(n=18)$} \\
\hline Instrumental range $\left(\mathrm{R}^{2}\right)$ & \multicolumn{3}{|c|}{$\begin{array}{c}\mathrm{y}=2885562 \mathrm{x}-54437.3 \\
(0.999)\end{array}$} & \multicolumn{3}{|c|}{$\begin{array}{c}\mathrm{y}=746.6882 \mathrm{x}-21.2936 \\
(0.999)\end{array}$} \\
\hline $\begin{array}{l}\text { Instrument and working } \\
\text { range } \mu \mathrm{g} / \mathrm{L}\end{array}$ & \multicolumn{3}{|c|}{$0.5-10$} & \multicolumn{3}{|c|}{$0.5-10$} \\
\hline Calculated LOD $(\mathrm{n}=10) \mu \mathrm{g} / \mathrm{L}$ & \multicolumn{3}{|c|}{0.164} & \multicolumn{3}{|c|}{0.162} \\
\hline Calculated LOQ $(\mathrm{n}=10) \mu \mathrm{g} / \mathrm{L}$ & \multirow{2}{*}{\multicolumn{3}{|c|}{$\frac{0.492}{0.5}$}} & \multirow{2}{*}{\multicolumn{3}{|c|}{$\frac{0.486}{0.5}$}} \\
\hline $\begin{array}{l}\text { Experimental LOQ } \\
\mu \mathrm{g} / \mathrm{L}\end{array}$ & & & & & & \\
\hline Trueness and Precision & $\begin{array}{l}\text { Low } \\
\text { level }\end{array}$ & $\begin{array}{c}\text { Medium } \\
\text { level }\end{array}$ & $\begin{array}{l}\text { High } \\
\text { level }\end{array}$ & $\begin{array}{l}\text { Low } \\
\text { level }\end{array}$ & $\begin{array}{c}\text { Medium } \\
\text { level }\end{array}$ & $\begin{array}{l}\text { High } \\
\text { level }\end{array}$ \\
\hline \multicolumn{7}{|l|}{ Trueness $(\mathrm{n}=21)$} \\
\hline Bias (\%) & 7.379 & -9.488 & -8.977 & -0.500 & -12.094 & -13.771 \\
\hline Recovery (\%) & 102.125 & 90.513 & 91.023 & 99.500 & 87.906 & 86.229 \\
\hline \multicolumn{7}{|l|}{ Precision $(\mathrm{n}=21, \mathrm{p}=3)$} \\
\hline RSDr (\%) & 7.379 & 11.765 & 11.707 & 12.860 & 10.649 & 6.331 \\
\hline $\mathrm{PRSD}_{\mathrm{R}}(\%)$ & 49.680 & 35.171 & 31.698 & 49.680 & 35.171 & 31.689 \\
\hline HorRat $_{\mathrm{r}}$ & 0.1 & 0.3 & 0.4 & 0.3 & 0.3 & 0.2 \\
\hline Uncertain $\mathrm{k}=2$ & \multicolumn{3}{|c|}{22.2} & \multicolumn{3}{|c|}{27.3} \\
\hline
\end{tabular}

$\mathrm{SD}=$ Standard deviation

$\mathrm{RSD}=$ Relative standard deviation.

$\alpha=$ Selectivity factor.

$\mathrm{R}_{\mathrm{s}}=$ Resolution.

$\mathrm{RSDr}=$ Relative Standard Deviation of Reproducibility

$\mathrm{PRSD}_{\mathrm{R}}=$ Predicted Relative Standard Deviation of Reproducibility

Table 5. Validation parameters of the analytical method for fish tissue. 


\begin{tabular}{|c|c|c|c|c|c|c|}
\hline Parameter & \multicolumn{3}{|c|}{ Ibuprofen } & \multicolumn{3}{|c|}{ Diclofenac } \\
\hline \multicolumn{7}{|l|}{ Linearity $(\mathrm{n}=18)$} \\
\hline Instrumental range $\left(\mathrm{R}^{2}\right)$ & \multicolumn{3}{|c|}{$\begin{array}{c}\mathrm{y}=9.996008 \mathrm{x}-26.9201 \\
(0.999)\end{array}$} & \multicolumn{3}{|c|}{$\begin{array}{c}\mathrm{y}=1.73502 \mathrm{x}-13.9505 \\
(0.998)\end{array}$} \\
\hline $\begin{array}{l}\text { Instrument and working } \\
\text { range ng/g }\end{array}$ & \multicolumn{3}{|c|}{$20-400$} & \multicolumn{3}{|c|}{$20-400$} \\
\hline Calculated LOD $(\mathrm{n}=10) \mathrm{ng} / \mathrm{g}$ & \multicolumn{3}{|c|}{5.420} & \multicolumn{3}{|c|}{5.856} \\
\hline Calculated LOQ $(\mathrm{n}=10) \mathrm{ng} / \mathrm{g}$ & \multicolumn{3}{|c|}{16.261} & \multicolumn{3}{|c|}{17.569} \\
\hline $\begin{array}{l}\text { Experimental LOQ } \\
\mathrm{ng} / \mathrm{g}\end{array}$ & \multicolumn{3}{|c|}{20} & \multicolumn{3}{|c|}{20} \\
\hline Trueness and Precision & $\begin{array}{l}\text { Low } \\
\text { level }\end{array}$ & $\begin{array}{l}\text { Medium } \\
\text { level }\end{array}$ & $\begin{array}{l}\text { High } \\
\text { level }\end{array}$ & $\begin{array}{l}\text { Low } \\
\text { level }\end{array}$ & $\begin{array}{l}\text { Medium } \\
\text { level }\end{array}$ & $\begin{array}{l}\text { High } \\
\text { level }\end{array}$ \\
\hline \multicolumn{7}{|l|}{ Trueness $(n=30)$} \\
\hline Bias (\%) & -18.046 & 7.760 & -14.766 & -13.497 & -15.457 & -18.227 \\
\hline Recovery (\%) & 81.954 & 107.760 & 85.234 & 86.503 & 84.543 & 81.073 \\
\hline \multicolumn{7}{|l|}{$\overline{\text { Precision }(n=30, p=3)}$} \\
\hline $\operatorname{RSDr}(\%)$ & 16.213 & 5.407 & 7.265 & 17.441 & 11.208 & 19.085 \\
\hline $\operatorname{PRSD}_{\mathrm{R}}(\%)$ & 28.568 & 20.224 & 18.227 & 28.568 & 20.224 & 18.227 \\
\hline HorRat $_{\mathrm{r}}$ & 0.6 & 0.3 & 0.4 & 0.6 & 0.6 & 1.0 \\
\hline
\end{tabular}

RSDr= Relative Standard Deviation of Reproducibility

$\mathrm{PRSD}_{\mathrm{R}}=$ Predicted Relative Standard Deviation of Reproducibility

Table 6. Concentrations of ibuprofen and diclofenac in water in the different seasons and sampling sites of the Cauca and Magdalena rivers, in the two years of sampling (Mean \pm SD).

\begin{tabular}{|c|c|c|c|c|c|c|c|}
\hline \multirow[t]{3}{*}{ iver } & \multirow[t]{3}{*}{ Site } & \multicolumn{6}{|c|}{ Season } \\
\hline & & \multicolumn{2}{|c|}{ Dry } & \multicolumn{2}{|c|}{ Transition } & \multicolumn{2}{|c|}{ Rainy } \\
\hline & & $\begin{array}{c}\text { Ibuprofen } \\
(\mu g / L)\end{array}$ & $\begin{array}{c}\text { Diclofenac } \\
(\mu \mathrm{g} / \mathrm{L})\end{array}$ & $\begin{array}{c}\text { Ibuprofen } \\
(\mu g / L)\end{array}$ & $\begin{array}{c}\text { Diclofenac } \\
(\mu \mathrm{g} / \mathrm{L})\end{array}$ & $\begin{array}{c}\text { Ibuprofen } \\
(\mu g / L)\end{array}$ & $\begin{array}{c}\text { Diclofenac } \\
(\mu \mathrm{g} / \mathrm{L})\end{array}$ \\
\hline \multirow[t]{5}{*}{ dalena } & Barrancabermeja & $<\mathrm{LOQ}$ & $<\mathrm{LOQ}$ & $<\mathrm{LOQ}$ & $0.68 \pm 0.23$ & $<\mathrm{LOQ}$ & $<\mathrm{LOQ}$ \\
\hline & La Dorada & $<\mathrm{LOQ}$ & $<\mathrm{LOQ}$ & $<\mathrm{LOQ}$ & $<\mathrm{LOQ}$ & $<\mathrm{LOQ}$ & $<\mathrm{LOQ}$ \\
\hline & Puerto Berrío & $<\mathrm{LOQ}$ & $<\mathrm{LOQ}$ & $<\mathrm{LOQ}$ & $<\mathrm{LOQ}$ & $<\mathrm{LOQ}$ & $<\mathrm{LOQ}$ \\
\hline & Puerto Serviez & $<\mathrm{LOQ}$ & $<\mathrm{LOQ}$ & $<\mathrm{LOQ}$ & $7.29 \pm 0.07$ & $<\mathrm{LOQ}$ & $<\mathrm{LOQ}$ \\
\hline & Puerto Triunfo & $<\mathrm{LOQ}$ & $<\mathrm{LOQ}$ & $<\mathrm{LOQ}$ & $0.94 \pm 0.52$ & $<\mathrm{LOQ}$ & $<\mathrm{LOQ}$ \\
\hline \multirow[t]{5}{*}{ iuca } & Caucasia & $<\mathrm{LOQ}$ & $\begin{array}{c}17.81 \pm \\
0.17\end{array}$ & $<\mathrm{LOQ}$ & $<\mathrm{LOQ}$ & $<\mathrm{LOQ}$ & $<\mathrm{LOQ}$ \\
\hline & Ciénaga Ayapel & $<\mathrm{LOQ}$ & $<\mathrm{LOQ}$ & $<\mathrm{LOQ}$ & $<\mathrm{LOQ}$ & $<\mathrm{LOQ}$ & $<\mathrm{LOQ}$ \\
\hline & Guarumo & $*$ & $*$ & $<\mathrm{LOQ}$ & $<\mathrm{LOQ}$ & $<\mathrm{LOQ}$ & $<\mathrm{LOQ}$ \\
\hline & La Apartada & $<\mathrm{LOQ}$ & $\begin{array}{c}12.20 \pm \\
16.55\end{array}$ & $<\mathrm{LOQ}$ & $<\mathrm{LOQ}$ & $<\mathrm{LOQ}$ & $<\mathrm{LOQ}$ \\
\hline & Nechí & $<\mathrm{LOQ}$ & $\begin{array}{c}67.54 \pm \\
10.61\end{array}$ & $<\mathrm{LOQ}$ & $<\mathrm{LOQ}$ & $<\mathrm{LOQ}$ & $<\mathrm{LOQ}$ \\
\hline
\end{tabular}

$\mathrm{LOD}=$ limit of detection $(0.164 \mu \mathrm{g} / \mathrm{L})$.

$\mathrm{LOQ}=$ limit of quantification $(0.500 \mu \mathrm{g} / \mathrm{L})$.

* The sample could not be taken.

Table 7. Concentrations of ibuprofen and diclofenac in catfish Pseudoplatystoma magdaleniatum in the different seasons and sampling sites of the Cauca and Magdalena rivers, in the two years of sampling (Mean $\pm \mathrm{SD}$ ). 


\begin{tabular}{|c|c|c|c|c|c|c|c|}
\hline \multirow[t]{3}{*}{ iver } & \multirow[t]{3}{*}{ Site } & \multicolumn{6}{|c|}{ Season } \\
\hline & & \multicolumn{2}{|c|}{ Dry } & \multicolumn{2}{|c|}{ Transition } & \multicolumn{2}{|c|}{ Rainy } \\
\hline & & $\begin{array}{c}\text { Ibuprofen } \\
(\mu \mathrm{g} / \mathrm{kg})\end{array}$ & $\begin{array}{c}\text { Diclofenac } \\
(\mu \mathrm{g} / \mathrm{kg})\end{array}$ & $\begin{array}{c}\text { Ibuprofen } \\
(\mu \mathrm{g} / \mathrm{kg})\end{array}$ & $\begin{array}{c}\text { Diclofenac } \\
(\mu \mathrm{g} / \mathrm{kg})\end{array}$ & $\begin{array}{c}\text { Ibuprofen } \\
(\mu \mathrm{g} / \mathrm{kg})\end{array}$ & $\begin{array}{c}\text { Diclofenac } \\
(\mu \mathrm{g} / \mathrm{kg})\end{array}$ \\
\hline \multirow[t]{5}{*}{ dalena } & Barrancabermeja & $<\mathrm{LOD}$ & $<\mathrm{LOD}$ & $<\mathrm{LOD}$ & $<\mathrm{LOD}$ & $<\mathrm{LOD}$ & $\begin{array}{c}7.80 \pm 1.41 \\
(<\mathrm{LOQ})\end{array}$ \\
\hline & La Dorada & $<\mathrm{LOD}$ & $<\mathrm{LOD}$ & $<\mathrm{LOD}$ & $<\mathrm{LOD}$ & $<\mathrm{LOD}$ & < LOQ \\
\hline & Puerto Berrío & $<\mathrm{LOD}$ & $<\mathrm{LOD}$ & $<\mathrm{LOD}$ & $<\mathrm{LOD}$ & $<\mathrm{LOD}$ & $\begin{array}{c}8.80 \pm 5.09 \\
(<\mathrm{LOQ})\end{array}$ \\
\hline & Puerto Serviez & $<\mathrm{LOD}$ & $<\mathrm{LOD}$ & $<\mathrm{LOD}$ & $<\mathrm{LOD}$ & $<\mathrm{LOD}$ & $\begin{array}{c}6.20 \pm 0.85 \\
(<\mathrm{LOQ})\end{array}$ \\
\hline & Puerto Triunfo & $<\mathrm{LOD}$ & $<\mathrm{LOD}$ & $<\mathrm{LOD}$ & $<\mathrm{LOD}$ & $<\mathrm{LOD}$ & $<\mathrm{LOQ}$ \\
\hline \multirow[t]{5}{*}{ tuca } & Caucasia & $<\mathrm{LOD}$ & $<\mathrm{LOD}$ & $<\mathrm{LOD}$ & $<\mathrm{LOQ}$ & $<\mathrm{LOD}$ & $<\mathrm{LOD}$ \\
\hline & Ciénaga Ayapel & $<$ LOD & $<\mathrm{LOD}$ & $<\mathrm{LOD}$ & $<\mathrm{LOQ}$ & $<\mathrm{LOD}$ & $<$ LOD \\
\hline & Guarumo & $*$ & $*$ & $<\mathrm{LOD}$ & $<\mathrm{LOQ}$ & $<\mathrm{LOD}$ & $<\mathrm{LOD}$ \\
\hline & La Apartada & $<\mathrm{LOD}$ & $<$ LOD & $<\mathrm{LOD}$ & $<\mathrm{LOQ}$ & $<\mathrm{LOD}$ & $<\mathrm{LOD}$ \\
\hline & Nechí & $<$ LOD & $<\mathrm{LOD}$ & $<\mathrm{LOD}$ & $<\mathrm{LOQ}$ & $<\mathrm{LOD}$ & $<\mathrm{LOD}$ \\
\hline
\end{tabular}

$\mathrm{LOD}=$ limit of detection $(5.00 \mathrm{\mu g} / \mathrm{kg})$.

$\mathrm{LOQ}=$ limit of quantification $(20.00 \mu \mathrm{g} / \mathrm{kg})$.

* The sample could not be taken.

Table 8. The concentration of ibuprofen and diclofenac in surface water and fish in different regions of the world. 


\begin{tabular}{|c|c|c|c|c|}
\hline $\begin{array}{l}\text { Pharmaceutical } \\
\text { compound }\end{array}$ & Matrix & 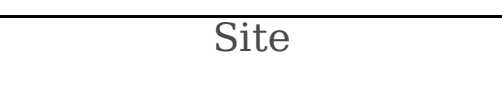 & Concentration & Reference \\
\hline \multirow[t]{13}{*}{ Ibuprofen } & \multirow[t]{11}{*}{ Water } & Pearl River, China & $78 \mathrm{ng} / \mathrm{L}$ (median) & $\begin{array}{c}\text { (Huang et al. } \\
\text { 2011) }\end{array}$ \\
\hline & & Yellow River, China & $2.4-416 \mathrm{ng} / \mathrm{L}$ & (Wang et al. 2010) \\
\hline & & Hai River, China & ND-127 ng/L & (Wang et al. 2010) \\
\hline & & Liao River, China & ND-246 ng/L & (Wang et al. 2010) \\
\hline & & River Segre, Spain & $\begin{array}{l}193 \mathrm{ng} / \mathrm{L} \text { (max. } \\
\text { conc.) }\end{array}$ & $\begin{array}{l}\text { (B. Huerta et al. } \\
\text { 2015) }\end{array}$ \\
\hline & & $\begin{array}{l}\text { Blue Lagoon Beach, } \\
\text { South Africa }\end{array}$ & $0.17 \mu \mathrm{g} / \mathrm{L}$ & $\begin{array}{c}\text { (Ngubane et al. } \\
\text { 2019) }\end{array}$ \\
\hline & & $\begin{array}{l}\text { Umgeni River, South } \\
\text { Africa }\end{array}$ & $0.28 \mu \mathrm{g} / \mathrm{L}$ & $\begin{array}{c}\text { (Ngubane et al. } \\
\text { 2019) }\end{array}$ \\
\hline & & Han River, South Korea & $100 \mathrm{ng} / \mathrm{L}$ (mean) & (Yoon et al. 2010) \\
\hline & & Begej River, Romania & $<\mathrm{LOQ}-346 \mathrm{ng} / \mathrm{L}$ & $\begin{array}{c}\text { (Petrović et al. } \\
\text { 2014) }\end{array}$ \\
\hline & & $\begin{array}{l}\text { Lee River, United } \\
\text { Kingdom }\end{array}$ & $3086 \mathrm{ng} / \mathrm{L}$ & (Ebele et al. 2017) \\
\hline & & $\begin{array}{c}\text { Thames River, United } \\
\text { Kingdom }\end{array}$ & $0.03-0.45 \mu \mathrm{g} / \mathrm{L}$ & (White et al. 2019) \\
\hline & \multirow[t]{2}{*}{ Fish } & $\begin{array}{c}\text { Al-Arbaeen Lagoon, } \\
\text { Saudi Arabia }\end{array}$ & $\begin{array}{c}\text { Gerres oyena } \\
<\mathrm{LOQ}-66.4 \mathrm{ng} / \mathrm{g} \\
\text { Chanos chanos } \\
<\mathrm{LOQ}-93.5 \mathrm{ng} / \mathrm{g}\end{array}$ & (Ali et al. 2018) \\
\hline & & $\begin{array}{l}\text { Lake Haapajärvi, } \\
\text { Finland }\end{array}$ & $\begin{array}{c}\text { Abramis brama } \\
\text { nd-34 ng/mL } \\
\text { (bile) } \\
\text { Rutilus rutilus } \\
\text { nd-26 ng/mL } \\
\text { (bile) }\end{array}$ & $\begin{array}{c}\text { (Brozinski et al. } \\
\text { 2013) }\end{array}$ \\
\hline \multirow[t]{12}{*}{ Diclofenac } & \multirow[t]{12}{*}{ Water } & Bogota River, Colombia & $0.40 \mu \mathrm{g} / \mathrm{L}$ (mean) & $\begin{array}{c}\text { (Botero-Coy et al. } \\
\text { 2018) }\end{array}$ \\
\hline & & $\begin{array}{c}\text { Medellin River, } \\
\text { Colombia }\end{array}$ & $\begin{array}{c}0.236 \mu \mathrm{g} / \mathrm{L} \\
(\mathrm{mean})\end{array}$ & $\begin{array}{c}\text { (Botero-Coy et al. } \\
2018)\end{array}$ \\
\hline & & Jundiai River, Brazil & $364 \mathrm{ng} / \mathrm{L}$ & $\begin{array}{l}\text { (Sathishkumar et } \\
\text { al. 2020) }\end{array}$ \\
\hline & & $\begin{array}{l}\text { Watershed in Sub- } \\
\text { Sahara, Cameroon }\end{array}$ & $419 \mathrm{ng} / \mathrm{L}$ & $\begin{array}{c}\text { (Sathishkumar et } \\
\text { al. 2020) }\end{array}$ \\
\hline & & Pearl River, China & $\begin{array}{l}119 \mathrm{ng} / \mathrm{L} \\
\text { (median) }\end{array}$ & $\begin{array}{c}\text { (Huang et al. } \\
\text { 2011) }\end{array}$ \\
\hline & & Yellow River, China & ND-136 ng/L & (Wang et al. 2010) \\
\hline & & Hai River, China & ND-46.5 ng/L & (Wang et al. 2010) \\
\hline & & Liao River, China & ND-717 ng/L & (Wang et al. 2010) \\
\hline & & Costa Rica & 266 ng/L & $\begin{array}{c}\text { (Sathishkumar et } \\
\text { al. 2020) }\end{array}$ \\
\hline & & Doubs River, France & $300 \mathrm{ng} / \mathrm{L}$ & $\begin{array}{l}\text { (Sathishkumar et } \\
\text { al. 2020) }\end{array}$ \\
\hline & & $\begin{array}{l}\text { Lake Tegel and Havel } \\
\text { River, Germany }\end{array}$ & $435 \mathrm{ng} / \mathrm{L}$ & $\begin{array}{l}\text { (Sathishkumar et } \\
\text { al. 2020) }\end{array}$ \\
\hline & & Apatlaco River Basin, & $1.4 \mu \mathrm{g} / \mathrm{L}$ & (Sathishkumar et \\
\hline
\end{tabular}




\begin{tabular}{|c|c|c|c|}
\hline & \multicolumn{2}{|l|}{ Mexico } & al. 2020) \\
\hline & $\begin{array}{c}\text { Irrigation canal, } \\
\text { Nigeria }\end{array}$ & $57.16 \mu \mathrm{g} / \mathrm{L}$ & $\begin{array}{l}\text { (Sathishkumar et } \\
\text { al. 2020) }\end{array}$ \\
\hline & Begej River, Romania & $<\mathrm{LOQ}-324$ & $\begin{array}{l}\text { (Petrović et al. } \\
\text { 2014) }\end{array}$ \\
\hline & $\begin{array}{c}\text { Sava River, Slovenia, } \\
\text { and Croatia }\end{array}$ & $4.62 \mathrm{ng} / \mathrm{L}$ & $\begin{array}{l}\text { (Sathishkumar et } \\
\text { al. 2020) }\end{array}$ \\
\hline & $\begin{array}{l}\text { Msunduzi River, South } \\
\text { Africa }\end{array}$ & $8.17 \mu \mathrm{g} / \mathrm{L}$ & $\begin{array}{l}\text { (Sathishkumar et } \\
\text { al. 2020) }\end{array}$ \\
\hline & Han River, South Korea & $67 \mathrm{ng} / \mathrm{L}$ (mean) & (Yoon et al. 2010) \\
\hline & Ebro River, Spain & $>100 \mathrm{ng} / \mathrm{L}$ & $\begin{array}{l}\text { (Sathishkumar et } \\
\text { al. 2020) }\end{array}$ \\
\hline & Höje River, Sweden & $120 \mathrm{ng} / \mathrm{L}$ & $\begin{array}{l}\text { (Sathishkumar et } \\
\text { al. 2020) }\end{array}$ \\
\hline & Llobregat River, Spain & $445.2 \mathrm{ng} / \mathrm{L}$ & $\begin{array}{l}\text { (Sathishkumar et } \\
\text { al. 2020) }\end{array}$ \\
\hline & $\begin{array}{l}\text { Turia River Basin, } \\
\text { Spain }\end{array}$ & $3.5 \mu \mathrm{g} / \mathrm{L}$ & $\begin{array}{c}\text { (Sathishkumar et } \\
\text { al. 2020) }\end{array}$ \\
\hline & $\begin{array}{l}\text { Lee river, United } \\
\text { Kingdom }\end{array}$ & $424 \mathrm{ng} / \mathrm{L}$ & (Ebele et al. 2017) \\
\hline & $\begin{array}{c}\text { Thames River, United } \\
\text { Kingdom }\end{array}$ & $0.0059-0.38 \mu \mathrm{g} / \mathrm{L}$ & (White et al. 2019) \\
\hline Fish & $\begin{array}{l}\text { Kalk Bay harbour, } \\
\text { South Africa }\end{array}$ & 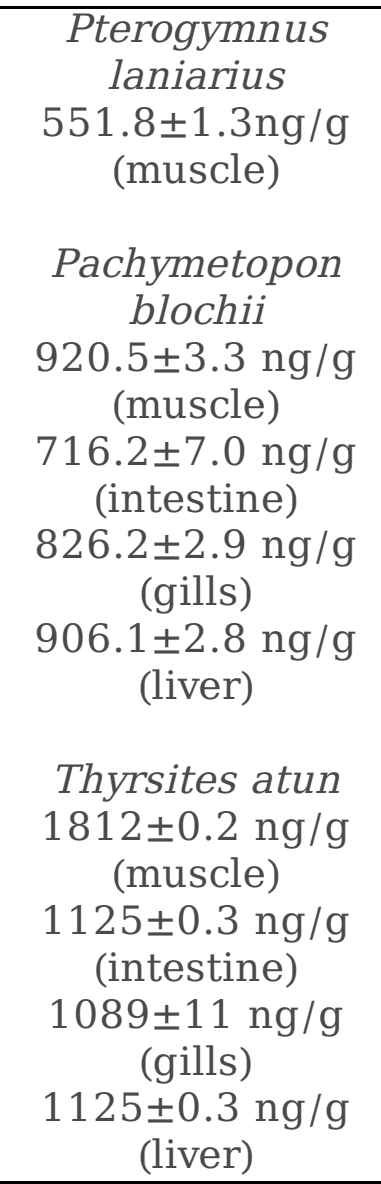 & $\begin{array}{c}\text { (Ojemaye and } \\
\text { Petrik 2019) }\end{array}$ \\
\hline & $\begin{array}{l}\text { Mar Menor lagoon, } \\
\text { Spain }\end{array}$ & $\begin{array}{c}\text { Liza aurata } \\
0.5 \pm 0.9 \mathrm{ng} / \mathrm{g} \\
\text { (liver) } \\
0.6 \pm 1.3 \mathrm{ng} / \mathrm{g} \\
\text { (liver) } \\
\end{array}$ & $\begin{array}{l}\text { (Moreno-González } \\
\text { et al. 2016) }\end{array}$ \\
\hline & Nanjing, China & Hemiculter & (Liu et al. 2015) \\
\hline
\end{tabular}




\begin{tabular}{|c|c|c|}
\hline & $\begin{array}{c}\text { leucisculus } \\
1.2 \mathrm{ng} / \mathrm{g} \text { (muscle) } \\
3.6 \mathrm{ng} / \mathrm{g} \text { (brain) } \\
1.5 \mathrm{ng} / \mathrm{g} \text { (gills) } \\
8.6 \mathrm{ng} / \mathrm{g} \text { (liver) } \\
\\
\text { Carassius auratus } \\
0.2 \mathrm{ng} / \mathrm{g} \text { (muscle) } \\
1.6 \mathrm{ng} / \mathrm{g} \text { (brain) } \\
0.1 \mathrm{ng} / \mathrm{g} \text { (gills) } \\
4.6 \mathrm{ng} / \mathrm{g} \text { (liver) }\end{array}$ & \\
\hline Guadalquivir, Spain & $\begin{array}{c}\text { ND-4.08 ng/g } \\
\text { (muscle) }\end{array}$ & \multirow[t]{4}{*}{ (Pico et al. 2019) } \\
\hline Júcar, Spain & $\begin{array}{c}\text { ND-11.76 ng/g } \\
\text { (muscle) }\end{array}$ & \\
\hline Ebro, Spain & $\begin{array}{c}\text { ND-5.72 ng/g } \\
\text { (muscle) }\end{array}$ & \\
\hline Llobregat, Spain & $\begin{array}{l}\text { ND-15.35 ng/g } \\
\text { (muscle) }\end{array}$ & \\
\hline $\begin{array}{l}\text { Al-Arbaeen Lagoon, } \\
\text { Saudi Arabia }\end{array}$ & $\begin{array}{c}\text { Gerres oyena } \\
25.1 \mathrm{ng} / \mathrm{g} \\
\text { (muscle) }\end{array}$ & (Ali et al. 2018) \\
\hline Rivers, United States & $\begin{array}{c}\text { White sucker } \\
0.7 \mathrm{ng} / \mathrm{g} \text { (muscle) }\end{array}$ & $\begin{array}{c}\text { (Belinda Huerta et } \\
\text { al. 2018) }\end{array}$ \\
\hline $\begin{array}{c}\text { Delaware, United } \\
\text { States }\end{array}$ & $\begin{array}{c}11930 \mu \mathrm{g} / \mathrm{L} \\
\text { (plasma) } \\
4.7 \mathrm{ng} / \mathrm{kg} \\
\text { (Predicted in fish) }\end{array}$ & (Bean et al. 2018) \\
\hline $\begin{array}{l}\text { Lake Haapajärvi, } \\
\text { Finland }\end{array}$ & $\begin{array}{c}\text { Abramis brama } \\
\text { nd-95 ng/mL } \\
\text { (bile) } \\
\text { Rutilus rutilus } \\
\text { nd-148 } \mathrm{ng} / \mathrm{mL} \\
\text { (bile) }\end{array}$ & $\begin{array}{c}\text { (Brozinski et al. } \\
\text { 2013) }\end{array}$ \\
\hline
\end{tabular}

ND: not detected.

Figures 


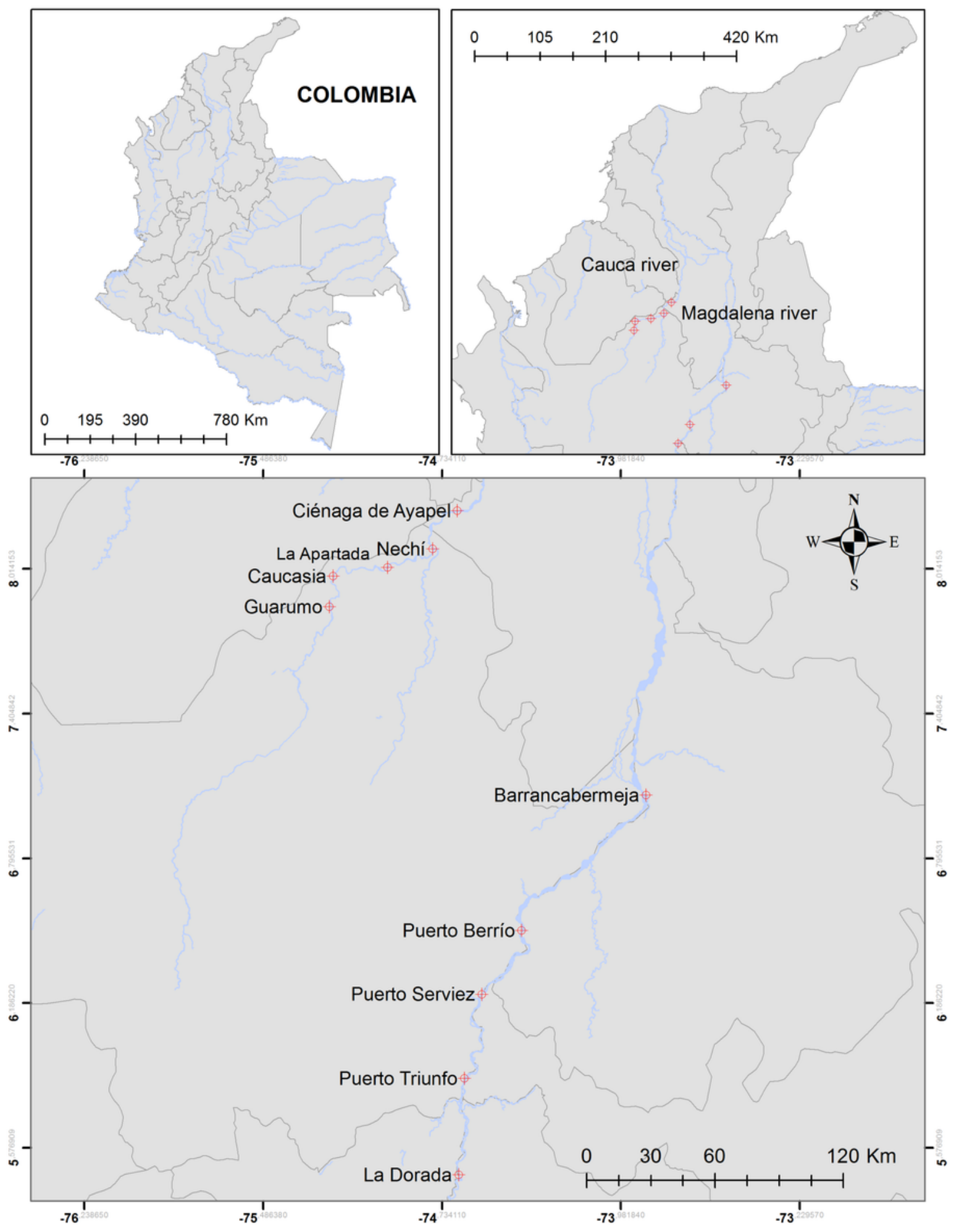

\section{Figure 1}

Map of the Cauca and Magdalena rivers and the different sampling points. 

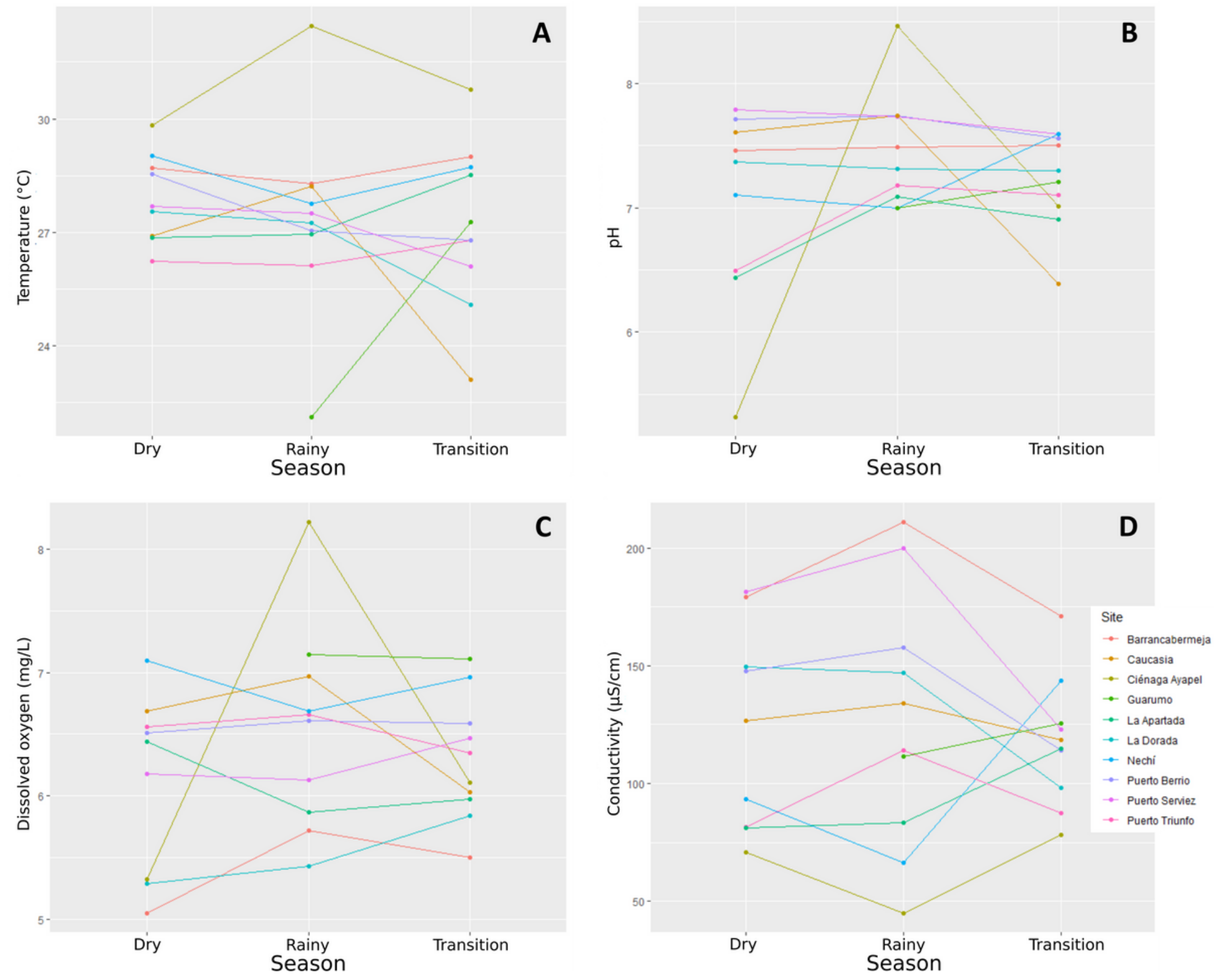

Figure 2

Physicochemical parameters measured in situ by climatic season and sampling site. Temperature (A), pH (B), Dissolved oxygen (C) and Conductivity (D). 